\title{
Viewpoint \\ Number crunching in the cancer stem cell market
}

Malcolm R Alison ${ }^{1}$, Shahriar Islam ${ }^{1}$ and Susan ML Lim²

\begin{abstract}
${ }^{1}$ Centre for Diabetes and Metabolic Medicine, ICMS, Barts and The London School of Medicine and Dentistry, 4 Newark Street, London E1 2AT, UK ${ }^{2}$ Department of Orthopaedic Surgery, National University of Singapore, 5 Lower Kent Ridge Road, Singapore 119074, Singapore
\end{abstract}

Corresponding author: Malcolm R Alison, m.alison@qmul.ac.uk

Published: 24 April 2009

This article is online at $h t t p: / /$ breast-cancer-research.com/content/11/2/302

(c) 2009 BioMed Central Ltd

Breast Cancer Research 2009, 11:302 (doi:10.1186/bcr2243)

breast and the colon [4], although the utility in colon cancer has been disputed [5].

In breast cancer cell lines, as few as $500 \mathrm{ALDH}^{+}$cells can form tumours in NOD/SCID mice [6]. From primary tumours that had cells positive not only for the familiar breast CSC signature $\left(\mathrm{CD} 44^{+} \mathrm{CD} 24^{-}\right)$but also for $\mathrm{ALDH}$, as few as 20 cells were tumorigenic; on the other hand, 50,000 CD $44^{+} \mathrm{CD} 24^{-} \mathrm{ALDH}^{-}$cells were nontumorigenic [7]. Breast cancers with cells expressing the CD44+CD24- phenotype are most common in basal-like tumours, but not all breast cancers contain a subpopulation with this phenotype [8], and in Brca1-deficient mouse mammary tumours there appear to be distinct $\mathrm{CD} 44^{+} \mathrm{CD} 24^{-}$and $\mathrm{CD} 133^{+}$subpopulations with stem cell properties [9] (see Figure 1). Moreover, within a tumour, cells may acquire stem cell properties through epithelial-mesenchymal transition (see Figure 1). Transformed human mammary epithelial cells with ectopic expression of the transcription factors Twist or Snail undergo epithelialmesenchymal transition with loss of E-cadherin and gain of vimentin; remarkably, almost all of these cells had the CD44+CD24- phenotype [10]. Selection for many of these putative CSCs is based upon expression levels of either the ABC superfamily of membrane transporters [2] or the aldehyde dehydrogenase $(A L D H)$ gene superfamily encoding detoxifying enzymes for many pharmaceuticals and environmental pollutants. As such, these CSCs are typically enriched after conventional treatments to which they are resistant.

The most popular marker of putative stem cells is seemingly Prominin-1 (CD133), the first identified member of the rapidly growing prominin family of pentaspan membrane proteins [3], with expression restricted to plasma membrane protrusions, such as epithelial microvilli. CD133 has been used to enrich for cells with tumour-initiating ability from a variety of human solid tumours, including the brain, the prostate, the liver, the

\section{Cancer stem cells: as rare as hen's teeth or as common as muck?}

Using the NOD/SCID assay, malignant melanoma initiating cells have been found to be rare amongst the unsorted tumour population $\left(\sim 1\right.$ in $\left.10^{6}\right)$ - but they can be enriched to about 1 in 158,000 when cells are sorted for the likely melanoma chemoresistance mediator ABCB5, a member of the $A B C$ transporter family [11]. Optimization of the assay, however, can drastically improve the tumorigenicity of the cells down to a level where even single cells can initiate tumour growth [12]. Using the standard NOD/SCID assay, limiting dilution assays - whereby between $10^{7}$ down to $10^{2}$ unsorted cells were transplanted - suggested that, as observed before, about 1 in 837,000 cells was a tumour- 
Figure 1

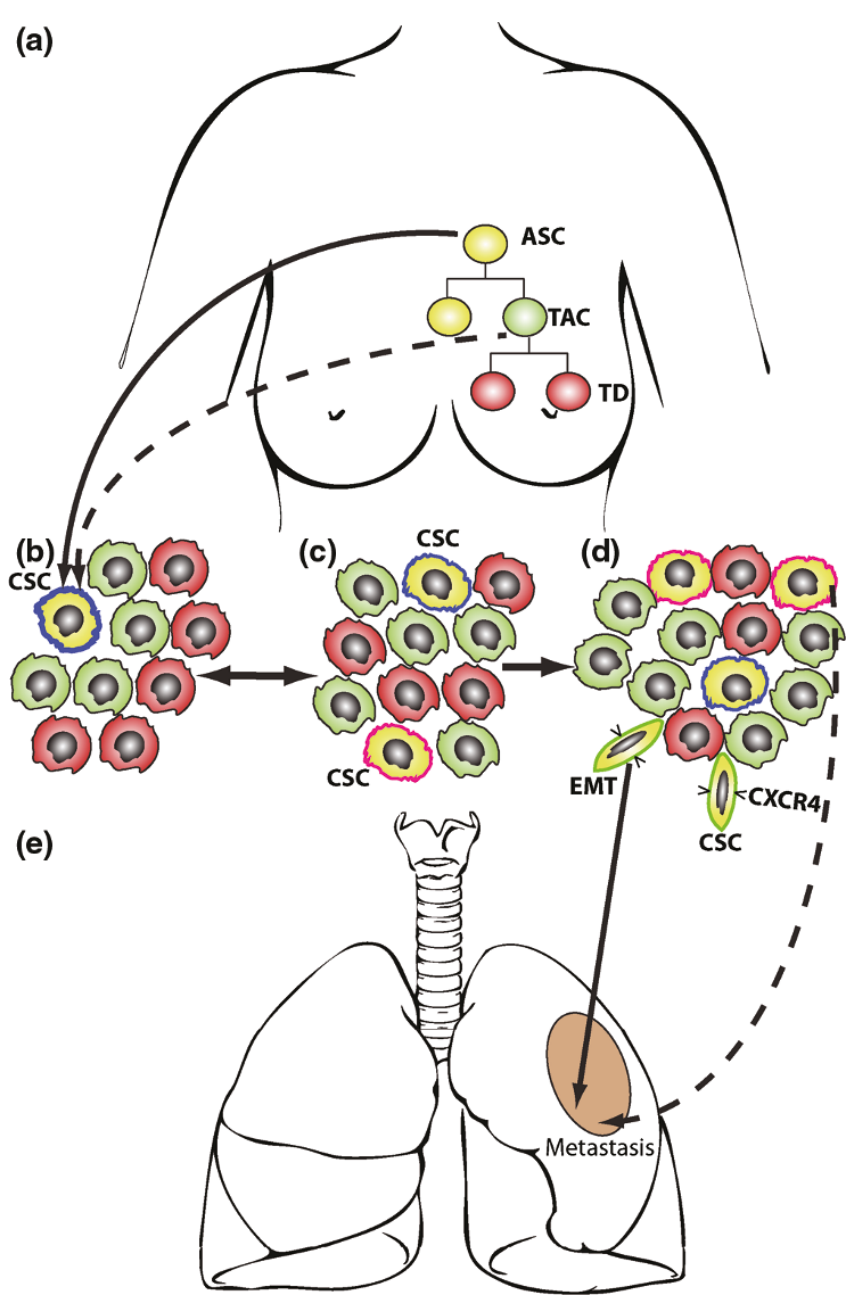

Current concepts regarding stem cells and tumour evolution in tissues with ordered structure. (a) In normal tissue, adult stem cells (ASC) (yellow) self-renew and give rise to transit amplifying cells (TAC) (green) that divide several times before undergoing terminal differentiation (TD) (red). Many lines of evidence, including direct lineage tracing from genetically marked ASC, indicate that tumours arise from ASC, although an origin from TAC is also possible.

(b) Tumours also have a hierarchical structure, albeit a relatively disorganized one. The cancer stem cells (CSCs) (yellow, blue border) may have a single phenotype and be rare or relatively common. (c) Genetic or epigenetic events may result in new clones driven by phenotypically diverse populations of CSCs. (d) Further genetic or epigenetic changes may result in some cells undergoing epithelial-mesenchymal transition (EMT), equipping them with CSC properties. (e) Metastasis may be caused by migrating CSCs detaching from the tumour mass; in particular, these may be the CSCs formed through EMT that may respond to chemotactic gradients by virtue of expression of chemokine receptors such as CXCR4.

initiating cell (TIC). Palpable tumours appeared earlier and grew faster when the transplanted cells were supported by Matrigel; when similarly prepared cells from primary tumours were transplanted to NOD/SCID $/ / 2 r \gamma^{/-}$mice, one in four cells was estimated to be a TIC. These recipient mice clearly represent a more permissive immune microenvironment, in particular lacking natural killer cell activity. Likewise, 254 single-cell transplantations derived from four patients yielded 69 tumours (a take rate of 27\%), again demonstrating a fantastic improvement in tumorigenicity with this new model.

\section{Refining the cancer stem cell hypothesis: not one cap fits all}

So is the CSC hypothesis dead or merely in need of modification? We would argue for the latter. Particularly in epithelial tissues with ordered structure, such as the epidermis, there is no doubt that many cells are undergoing terminal differentiation - in fact, all of the suprabasal cells. Likewise, in epidermal squamous cell carcinomas - particularly well-differentiated ones - many cells are reproductively sterile; for example, the cells comprising the pearls of keratinized squames - clearly less than one in four of these tumour cells are TICs.

So are malignant melanomas unrepresentative of the majority of tumours? Perhaps in some respects they are; for example, metastases typically occur very early in tumour development, melanomas are one of the few tumours where the isolated cells are highly resistant to apoptosis (anoikis) [13], and, with respect to epithelial mesenchymal transition, melanocytes developmentally upregulate transcription factors such as Slug during migration from the neural crest. On the other hand, melanocytes can divide and are renewed from the hair follicle bulge region, and are responsive to differentiating influences [14].

Despite the caveats regarding malignant melanoma, this new study alerts us to the fact that the NOD/SCID assay merely identifies cells able to form tumours in a hostile murine environment, and that many factors conspire to vastly underestimate the frequency of TICs. These include the absence of a niche for the transplanted cells (partially mimicked by Matrigel), and the recipient's residual immune system. These assertions are underscored by the fact that as few as 10 mouse lymphoma or acute myeloid leukaemia cells can regularly propagate tumours when transplanted into histocompatible mice [15]. So are all cells in these tumours possible TICs?

The rarity of cancer stem cells has also been questioned in mouse mammary cancer. Using up to a dozen murine mammary cancer cell lines, cell colonies could be regularly generated from randomly selected single cells; and when $2 \times 10^{5}$ cells from these clonally derived colonies were allografted into histocompatible mice, tumours were consistently produced suggesting that perhaps the TICs do not have a unique surface marker signature [16]. On the other hand, cell sorting of heterogeneous mammary tumour cells from p53-null Balb/c mice has identified a distinct subset of CD29high CD24 ${ }^{\text {high Lin- }}{ }^{-}$ cells that were highly enriched for TICs when transplanted into the cleared fat pads of syngeneic wild-type Balb/c mice [17]. 
Limiting dilution transplantation experiments certainly supported the CSC hypothesis, and the small numbers of cells transplanted (100 cells) to obtain heterogeneous tumours indicated that perhaps the TICs were at least bipotential. The question of whether tumour heterogeneity is due to distinct clones from different CSCs or whether CSCs, like their normal counterparts, are multipotential is of fundamental importance. This question has been answered in colorectal cancer; clonal populations derived from a colorectal cancer cell line and from primary colorectal cancer can subsequently recapitulate the heterogeneity of the original tumours when transplanted in nude mice, exhibiting enterocytic, neuroendocrine and goblet cell differentiation all from a single cell $[18,19]$.

\section{Conclusions}

The CSC hypothesis is not dead, but it needs refining to accommodate the likelihood that the frequency of CSCs may vary from tumour to tumour and is likely to change during tumour progression by both epithelial-mesenchymal transition as well as by the symmetric cell division of CSCs themselves.

\section{Competing interests}

The authors declare that they have no competing interests.

\section{References}

1. Hamburger AW, Salmon SE: Primary bioassay of human tumor stem cells. Science 1977, 197:461-463.

2. 49 Human ATP-binding Cassette Transporters [http://www. nutrigene.4t.com/humanabc.htm]

3. Mizrak D, Brittan M, Alison MR: CD133: molecule of the moment. J Pathol 2008, 214:3-9.

4. Alison MR, Murphy G, Leedham S: Stem cells and cancer: a deadly mix. Cell Tissue Res 2008, 331:109-124.

5. Shmelkov SV, Butler JM, Hooper AT, Hormigo A, Kushner J, Milde T, St Clair R, Baljevic M, White I, Jin DK, Chadburn A, Murphy AJ, Valenzuela DM, Gale NW, Thurston G, Yancopoulos GD, D'Angelica M, Kemeny N, Lyden D, Rafii S: CD133 expression is not restricted to stem cells, and both $\mathrm{CD}^{2} 3^{+}$and $\mathrm{CD}^{-133^{-}}$ metastatic colon cancer cells initiate tumors. J Clin Invest 2008, 118:2111-2120.

6. Charafe-Jauffret E, Ginestier C, lovino F, Wicinski J, Cervera N, Finetti $P$, Hur MH, Diebel ME, Monville F, Dutcher J, Brown M, Viens P, Xerri L, Bertucci F, Stassi G, Dontu G, Birnbaum D, Wicha MS: Breast cancer cell lines contain functional cancer stem cells with metastatic capacity and a distinct molecular signature. Cancer Res 2009, 69:1302-1313.

7. Ginestier C, Hur MH, Charafe-Jauffret E, Monville F, Dutcher J, Brown M, Jacquemier J, Viens P, Kleer CG, Liu S, Schott A, Hayes D, Birnbaum D, Wicha MS, Dontu G: ALDH1 is a marker of normal and malignant human mammary stem cells and a predictor of poor clinical outcome. Cell Stem Cell 2007, 1:555567.

8. Honeth G, Bendahl PO, Ringnér M, Saal LH, Gruvberger-Saal SK, Lövgren K, Grabau D, Fernö M, Borg A, Hegardt C: The CD44+/CD24- phenotype is enriched in basal-like breast tumors. Breast Cancer Res 2008, 10:R53.

9. Wright $M H$, Calcagno AM, Salcido CD, Carlson MD, Ambudkar SV, Varticovski L: Brca1 breast tumors contain distinct $\mathrm{CD}^{-} 4^{+} / \mathrm{CD} 24^{-}$and $\mathrm{CD} 133^{+}$cells with cancer stem cell characteristics. Breast Cancer Res 2008, 10:R10.

10. Mani SA, Guo W, Liao MJ, Eaton EN, Ayyanan A, Zhou AY, Brooks M, Reinhard F, Zhang CC, Shipitsin M, Campbell LL, Polyak K, Brisken C, Yang J, Weinberg RA: The epithelial-mesenchymal transition generates cells with properties of stem cells. Cell 2008, 133:704-715.
11. Schatton T, Murphy GF, Frank NY, Yamaura K, Waaga-Gasser AM, Gasser M, Zhan Q, Jordan S, Duncan LM, Weishaupt C, Fuhlbrigge RC, Kupper TS, Sayegh MH, Frank MH: Identification of cells initiating human melanomas. Nature 2008, 451:345349.

12. Quintana E, Shackleton M, Sabel MS, Fullen DR, Johnson TM, Morrison SJ: Efficient tumour formation by single human melanoma cells. Nature 2008, 456:593-598.

13. Frisch SM, Screaton RA: Anoikis mechanisms. Curr Opin Cell Biol 2001, 13:555-562.

14. Gerschenson M, Graves K, Carson SD, Wells RS, Pierce GB: Regulation of melanoma by the embryonic skin. Proc Natl Acad Sci U S A 1986, 83:7307-7310.

15. Kelly PN, Dakic A, Adams JM, Nutt SL, Strasser A: Tumor growth need not be driven by rare cancer stem cells. Science 2007, 317:337.

16. Yoo MH, Hatfield DL: The cancer stem cell theory: is it correct? Mol Cells 2008, 26:1-10.

17. Zhang M, Behbod F, Atkinson RL, Landis MD, Kittrell F, Edwards D, Medina D, Tsimelzon A, Hilsenbeck S, Green JE, Michalowska AM, Rosen JM: Identification of tumor-initiating cells in a p53null mouse model of breast cancer. Cancer Res 2008, 68: 4674-4782.

18. Kirkland SC: Clonal origin of columnar, mucous, and endocrine cell lineages in human colorectal epithelium. Cancer 1988, 61:1359-1363.

19. Vermeulen L, Todaro M, de Sousa Mello F, Sprick MR, Kemper K, Perez Alea M, Richel DJ, Stassi G, Medema JP: Single-cell cloning of colon cancer stem cells reveals a multi-lineage differentiation capacity. Proc Natl Acad Sci U S A 2008, 105: 13427-13432. 